\title{
RANCANG BANGUN ALAT UJI IMPACT METODE CHARPY
}

\author{
Mochammad Khoirul Huda1, Galih Setia Aji ${ }^{2}$ \\ Teknik Mesin, Fakultas Teknik \\ Universitas Maarif Hasyim Latif, Sidoarjo, Indonesia \\ e-mail : $\underline{\text { mkhoirulh1@gmail.com¹ }}$ galihsetiaaji8@gmail.com²
}

\begin{abstract}
ABSTRAK
Pengujian impact merupakan suatu pengujian untuk mengukur ketahanan bahan terhadap beban kejut. Pengujian impact ini mensimulasikan kondisi operasi material yang sering ditemui dimana beban tidak selamanya terjadi secara perlahan-lahan melainkan datang secara tiba-tiba. Tujuan yang ingin dicapai dalam perancangan ini adalah untuk menyempurnakan alat uji impact dengan metode charpy dengan menyesuaikan standard alat uji impact metode charpy yang sudah ada di salah satu laboratorium universitas di surabaya dan juga yang ada di pasaran. Perancangan ini menghasilkan alat uji impact metode charpy yang dapat mendukung parktikum uji impact di laboratorium teknik Mesin Universitas Ma'arif Hasyim Latif Sepanjang Sidoarjo. Hasil akhir dari perancangan alat uji impact metode charpy ini adalah mempunyai dimensi alat dengan ukuran $1143 \mathrm{~mm}$ x $400 \mathrm{~mm}$ x $1180 \mathrm{~mm}$, mendapatkan Energi Potensial sebesar 263.89 Joule, mendapatkan momen pada poros penggerak pendulum sebesar $M=7729,2 \mathrm{Nmm}$, dan mengalami Tegangan Lentur ( $\sigma a)$ sebesar $1899,707 \mathrm{~N} / \mathrm{mm}^{2}$. Dan juga mengalami Tegangan Geser $(\sigma a)$ sebesar $4,83 \mathrm{~kg} / \mathrm{mm}^{2}$.
\end{abstract}

Kata kunci: Energi Potensial, Metode Charpy, Tegangan Geser, Tegangan Lentur, Pengujian Impact

\section{PENDAHULUAN}

Dengan berdirinya laboratorium teknik mesin di Universitas Hasyim Latif Sidoarjo yang setahap demi setahap melengkapi peralatan yang diperlukan untuk menunjang praktikum uji material mahasiswa. Sehingga disusunlah tugas akhir yang berjudul " RANCANG BANGUN ALAT UJI IMPACT METODE CHARPY ", bermaksud untuk melengkapi peralatan uji metalografi pada laboratorium teknik mesin di Universitas Hasyim Latif Sidoarjo.

Dalam dunia permesinan ataupun di bidang teknik mesin, pasti kita melakukan praktek kerja, melakukan penelitian,mengetahui kekuatan bahan dan sebagainya yang di mana hal tersebut ada hubungannya dengan teknik mesin. Ada beberapa alat yang di ciptakan sebagai alat untuk pengujian salah satunya yaitu alat uji impact. Pengujian impact (ketangguhan) adalah alat yang digunakan untuk mengetahui nilai ketahanan bahan terhadap adanya beban yang datang secara tiba-tiba(mendadak). Dalam pengujian impact ini dapat di lakukan dengan dua metode, yaitu :

1. Metode izod

Metode izod ialah mempunyai penampang lintang bujur sangkar atau lingkaran yang bertakik $\mathrm{V}$ didekat ujung yang dijepit. Pada cara ini spesiment pada salah satu ujungnya sehingga takik akan berada dekat permukaan penjepitnya.

2. Metode charpy

Pada cara ini batang uji diletakkan mendatar oleh penahan yang berjarak $40 \mathrm{~mm}$, kemudian bandul akan memukul spesiment dari arah yang bertakik. Benda uji charpy mempunyai luas penampang lintang bujur sangkar ( 10 x $10 \mathrm{~mm}$ ) dan mengandung takik V-45을 , dengan jari-jari datar 0,25 $\mathrm{mm}$ dan kedalaman $2 \mathrm{~mm}$, kecepatan impact sekitar $16 \mathrm{ft} /$ detik. Benda uji akan melenkung dan patah pada laju regangan yang tinggi, kira-kira $10^{3}$ detik.

Dalam hal ini kami membahas tentang proses redesain alat uji impact metode charpy ini dengan mengubah proses pengangkatan pendulum dengan pemberian roda gigi pada alat uji impact tersebut, dan juga menambahi dengan memberi pengereman untuk menghentikan laju pendulum ketika selesai memukul spesimen tersebut.

\section{METODE PENELITIAN}

\section{Waktu dan Tempat \\ Waktu}

Analisa, perancangan, pembuatan dan pengujian alat dilaksanakan selama \pm 3 bulan berdasarkan pada jadwal yang ditentukan.

Tempat

Tempat pelaksanaan perancangan dan pembuatan Alat Uji Impact Dengan Metode Charpy inidi kerjakan di bengkel UD. HADI PUTRA ENGINEERING.

\section{Prosedur Tugas Akhir}

Dalam pelaksanaan pembuatan tugas akhir ini melalui beberapa prosedur pengujian sebagai berikut: 


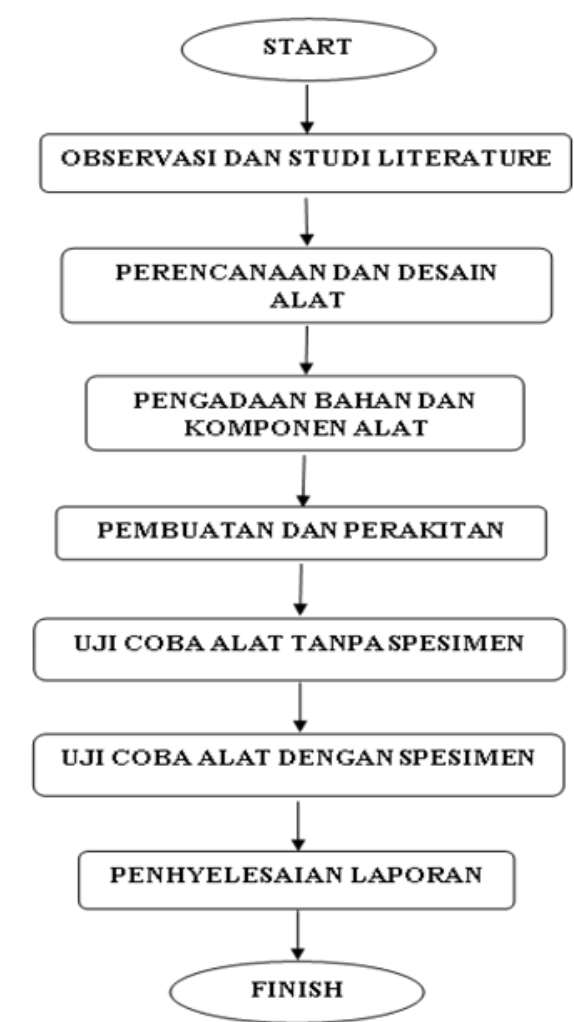

Gambar 1. flow chart metode perencanaan

1. Observasi

2. Survey dilakukan dengan cara mensurvey alat uji impactyang sudah ada serta mengamati mekanisme dari alat tersebut.

3. Studi Literatur

Perencanaan kontruksi ini berdasarkan literatur yang mempunyai relevansi dengan permasalahan yang akan dihadapi, baik dari buku teks, jurnal, penelitian dan lain - lain, hal ini dimaksudkan untuk memperoleh data teknis mengenai segala hal yang berhubungan dengan alat uji impact.

4. Perencanaan dan Desain Gambar

Desain alat yang dimaksud adalah untuk merencanakan alat uji impact dengan memperhatikan data-data yang diperoleh dari studi literatur maupun observasi lapangan. Setelah desain gambar, akan dilakukan perhitungan tentang gaya - gaya ( elemen elemen ) yang terjadi untuk menentukan bahan. Yang kemudian digunakan untuk membuat alat itu.

5. Pengadaan Alat

Dalam tahap ini dilakukan pemilihan bahan sesuai dengan hasil perhitungan yang bertujuan mengenai batas - batas tegangan yang diijinkan untuk membuat alat (apa bahannya ).

6. Pembuatan dan Perakitan Alat

Dengan hasil perhitungan perencanaan alat dan gaya yang terjadi, maka didapatkan kebutuhan akan bahan yang akan digunakan untuk pembuatan alat, maka perakitannya dilakukan secara sistematis berdasarkan perencanaan dan sifat - sifat bahan agar tidak terjadi kerusakan pada waktu pengoperasiannya.

7. Uji Coba
Setelah perakitan dan perwujudan alat sudah selesai, dan alat sudah mulai bisa dioperasikan, maka dilakukan uji coba untuk menguji kemampuan alat, apakah sesuai dengan apa yang kita harapkan atau tidak. Jika uji coba gagal atau alat tidak sesuai dengan yang kita kehendaki, maka harus dilakukan pengecekan ulang dari desain gambar dan perhitungan alat.

8. Penyusunan Laporan

Setelah mendapatkan data - data yang diperlukan dari hasil perhitungan dan perwujudan alat, maka dibuat laporan mengenai hasil rancangan atau pembuatan alat dan sistem kerja alat tersebut. Diagram Alir (flowchart)

\section{HASIL DAN PEMBAHASAN}

\section{Desain rancang bangun alat uji impact metode charpy}

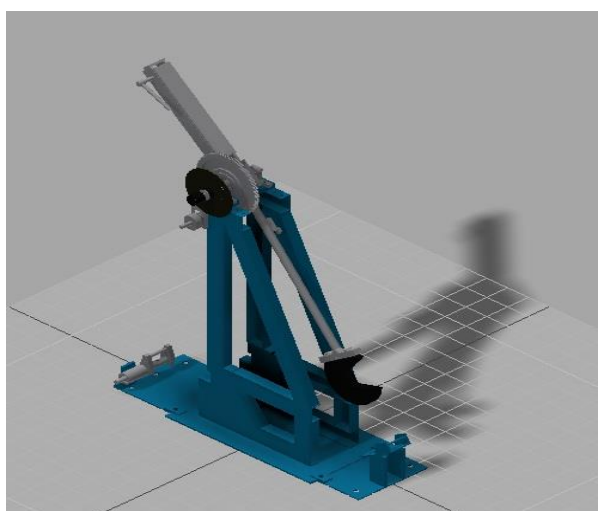

Gambar 2. Desain alat uji impact metode charpy

Alat uji impact metode charpy adalah sebuah alat uji tes kekerasan material yang dimana spesimen mendapatkan beban kejut secara tiba-tiba dari suatu pendulum yang akan menunjukkan hasil kekerasan dari spesimen tersebut.

\section{Material uji ( spesimen )}

Dalam pengujian alat uji impact dengan metode charpy ini kita menggunakan material yang berbeda dengan ukuran yang sama. Material yang kita gunakan yaitu material s $45 \mathrm{c}$ dan material st 37 . Berikut ini desain spesimen yang digunakan saat pengujian dengan menyesuaikan alat uji impact dengan metode charpy yang kami rancang :
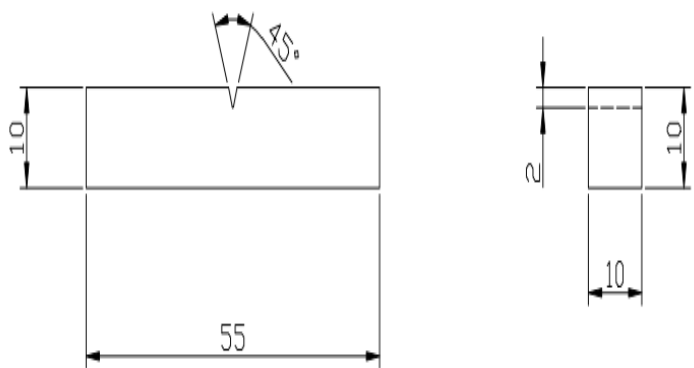

Gambar 3. Spesimen Bahan Uji 
Spesifikasi Alat Uji Impact dengan Metode Charpy

Adapun spesifikasi alat uji impact dengan metode charpy ini adalah sebagai berikut:

Tipe alat uji

Kapasitas

Berat gondam (pendulum)

:Charpy

: 200 Joule

$: 16 \mathrm{Kg}$

Jarak titik ayun dengan titik puku

: $953 \mathrm{~mm}$

Posisi awal pemukulan

$: 140 \mathrm{o}$

$: 300$

Sudut pisau pemukul

$: 1143 \mathrm{~mm} \times 400 \mathrm{~mm}$

Dimensi alat uji

$\mathrm{x} 1180 \mathrm{~mm}$

Standar bahan uji

: Aluminium

Alat uji impact dengan metode charpy mempunyai beberapa bagian-bagian utama yang terdiri dari :

1. Pengunci pendulum

2. Lengan untuk pengangkatan pendulum

3. Poros penggerak

4. Roda gigi besar

5. Penampang papan derajat

6. Jarum utama dan jarum gerak derajat

7. Tatakan penyangga engkolan

8. Roda gigi kecil

9. Poros penggerak roda gigi kecil

10. Rumah poros penggerak roda gigi kecil

11. Handle engkolan manual

12. Dudukan spesimen

13. Poros penggerak rem dan penyangga rem

14. Rumah porors penggerak rem

15. Tatakan rem 1

16. Tatakan rem 2

17. Handle pengereman

18. Penhubung antara pendulum dan poros penggerak

19. Lengan pengayun pendulum

20. Pendulum

21. Rangka

\section{Perhitungan Komponen Alat Uji}

Untuk mendapatkan suatu mekanisme yang mampu memenuhi persyaratan, maka perlu dilakukan pemilihan komponen penyusunnya yang nantinya dirangkai menjadi satu kesatuan sistem alat uji impak metode charpy. Berikut akan dibahas dibahas satu persatu persatu komponen penyusun yang akan digunakan dan diharapkan dapat membentuk satu kesatuan alat uji yang dapat digunakan untuk melakukan pengujian.

\section{Pengujian Alat Uji Impact Metode Charpy tanpa Spesimen}

Setelah semua proses pengerjaan selesai, maka dilakukan assembling dengan menyesuaikan desain yang kami buat. Dan setelah proses assembling selesai maka dilakukan pengujian. Pengujian pertama sesuai dengan standart alat uji impact yang pernah kami observasi di laboratorium salah satu universitas di surabaya, pengujian tanpa spesimen menunjukkan bahwa dimana posisi awal pendulum kita di posisi $140^{\circ}$, kemudian pendulum dilepas dan posisi akhir pendulum menunjukkan angka 140 o.

Begitupun pengujian pada alat uji impact metode charpy yang kami buat, kami lakukan pengujian tanpa spesimen dengan posisi awal pendulum yaitu $140^{\circ}$, kemudian pedulum kami lepaskan dan posisi akhir pendulum menunjukkan angka 135‥

Setelah pengujian tanpa spesimen kami lakukan dan hasilnya tidak sesuai dengan hasil pengujian yang kami lakukan dengan alat uji impact metode charpy di laboratorium universitas di surabaya, maka ada faktor yang mempengaruhi terjadinya hal tersebut, seperti Posisi alat uji impact metode charpy yang kami buat disaat kami uji tidak seimbang (karena belum di cor, akibatnya ketika pendulum dilepas terjadi goyangan pada alat uji tersebut).

\section{Pengujian dengan Spesimen}

Dalam pengujian dengan spesimen ini kami menggunakan material yang berbeda . material yang kami gunakan untuk pengujian adalah S 45 C dan ST37( Gambar 4.9 dan 4.10). Dalam pengujian sebelumnya yaitu pengujian tanpa spesimen didapatkan hasil yaitu posisi awal pendulum $140^{\circ}$ dan posisi akhir pendulum $135^{\circ}$, kurang $5^{\circ}$ untuk mencapai standard alat uji impact metode charpy yang ada pasaran yaitu posisi awal pendulum $140^{\circ}$ o dan posisi akhir pendulum $140^{\circ}$, maka untuk mengetahui energi yang di serap dapat dihitung dengan rumus sebagai berikut:

Energi yang diserap $\left.=m \cdot g \cdot l\left((1+\sin \beta)-1-\cos \alpha+5^{\circ}\right)\right)$ Keterangan:

$\mathrm{m}=$ Berat Pendulum $(\mathrm{Kg})$

$\mathrm{g}=$ Gravitasi $9,81 \mathrm{~m} / \mathrm{s} 2$

$1=$ Jarak lengan pengayun $(\mathrm{m})$

$\cos \alpha=$ Sudut posisi akhir pendulum

$\sin \beta=$ Sudut posisi awal pendulum

Untuk mengetahui harga impact, dapat dihitung dengan rumus sebagai berikut:

$$
K=\frac{\text { Energi yang Diserap } .(U)}{A}
$$

Dimana : $\mathrm{K}=$ harga impak $\left(\mathrm{Kgm} / \mathrm{mm}^{2}\right)$

$$
\mathrm{J}=\text { Energi yang diserap ( Joule ) }
$$

$\mathrm{A}=$ Luas Penampang $\left(\mathrm{mm}^{2}\right)$

\section{Menghitung Tegangan Lentur/Lengkung pada Poros}

diketahui momen terbesar $\mathrm{M}=7729,2 \mathrm{Nmm}$ dan diameter poros $41,5 \mathrm{~mm}$, maka dapat dihitung tegangan lengkung sebagai berikut:

$$
\begin{gathered}
\sigma_{a}=\frac{10,2 M_{1}}{d_{s}^{3}} \\
=\frac{10,2 \times 7729,2 \mathrm{Nmm}}{41,5 \mathrm{~mm}^{2}} \\
=1899,707 \mathrm{~N} / \mathrm{mm}^{2}
\end{gathered}
$$

Jadi dapat diketahui bahwa tegangan lentur yang dialami oleh poros penggerak pendulum sebesar $1899,707 \mathrm{~N} / \mathrm{mm}^{2}$. 


\section{PENUTUP}

\section{Kesimpulan}

Beberapa kesimpulan yang dapat diketahui dari perancangan alat uji impact metode charpy yang kami buat adalah sebagai berikut:

1. Desain rancang bangun alat uji impact metode charpy ini mempunyai ukuran $1143 \mathrm{~mm}$ x $400 \mathrm{~mm}$ x $1180 \mathrm{~mm}$.

2. Proses pembuatan rancang bangun alat uji impact metode charpy ini adalah:
a. Persiapan gambar kerja dan desain alat.
b. Persiapan bahan yang akan digunakan.
c. Proses marking, cutting, turning, milling, grinding, drilling, welding, dan shaping.
d. Proses perakitan.
e. Proses finishing dengan pengecatan alat.
f. Uji coba alat.

3. Kapasitas alat uji impact metode dengan charpy sebesar 200 joule.

4. Energi potensial yang diperoleh alat uji impact metode charphy yang kami rancang sebesar 263.89 Joule.

5. Momen terbesar yang dihasilkan sebesar $\mathrm{M}=$ 7729,2 Nmm, tegangan lentur yang di alami sebesar $1899,707 \mathrm{~N} / \mathrm{mm}^{2}$, dan tegangan geser yang di alami sebesar $4,83 \mathrm{~kg} / \mathrm{mm}^{2}$.

\section{Saran}

Saran-saran yang dapat di sampaikan adalah sebagai berikut :

1. Pengujian uji impactsebaiknya di lakukan minimal 2 orang.

2. Perawatan alat dengan melumasi bagian-bagian yang mudah berkarat.

3. Selalu mengontrol sebelum dan sesudah menggunakan alat tersebut.

4. Mendesain merancang ulang roda gigi untuk proses pengangkatan dikarenakan hasil yang kami rancang belum maksimal.

5. Menambah mekanisme pengangkat (motor listrik), sehingga saat menaikkan bandul keatas pengunci bisa dilakukan secara otomatis.

\section{DAFTAR PUSTAKA}

Handoyo Yopi, (2013). Perancangan Alat Uji Impak Metode Charpy Kapasitas 100 Joule. Universitas Islam 45. Jurnal Imiah Teknik Mesin, 1(2), 45-53.

Hardiana, F., Budiman, H., Samantha, Y. (2000). Perancangan Alat Uji Impak Metode Charpy Dan Izod. Universitas Majalengka. 248-252

http://jurnal.unma.ac.id/index.php/ST/arti cle/view/249/233
Umam Nasrul. (2015). Analisis Uji Impact Pada Baja St60 Dengan Variasi Ketebalan Lapisan Karbon Fiber Untuk Aplikasi Kerangka Mobil Listrik. Fakultas Teknik, Universitas Negeri Semarang.

Wardani, C.U., Samantha Y., Budiman H. (2000). Analisis Pengujian Impak Metoda Izod Dan Charpy Menggunakan Benda Uji Alumunium Dan Baja St37. Fakultas Teknik, Universitas Majalengka. 
MK Huda, dkk / Mechonversio, Vol. 1, No.1, Desember 2018, 7-11

Halaman ini sengaja dikosongkan 